\title{
PENGARUH PERPUTARAN PIUTANG TERHADAP NILAI PERUSAHAAN PADA PERUSAHAAN SUB SEKTOR TEKSTIL DAN GARMEN YANG LISTING DI BURSA EFEK INDONESIA
}

\author{
Oleh: \\ Olimvia Agus Santi Purba \\ S1 Akuntansi \\ Yansen Siahaan, Rosanna Purba, Elly Susanti
}

Abstraksi

Penelitian ini bertujuan untuk menganalisis pengaruh perputaran piutang terhadap nilai perusahaan yang diproksikan dengan market to book ratio pada Perusahaan Sub Sektor Tekstil dan Garmen yang listing di Bursa Efek Indonesia. Penelitian ini dilakukan dengan menggunakan metode analisis deskriptif kualitatif dan analisis deskriptif kuantitatif. Sampel yang digunakan adalah Perusahaan Sub Sektor Tekstil dan Garmen yang listing di Bursa Efek Indonesia tahun 2009 - 2013 yang telah memenuhi kriteria penarikan sampel berdasarkan purposive sampling yaitu sebanyak 15 perusahaan.

Hasi regresi menunjukkan bahwa Perputaran Piutang berpengaruh negatif dan signifikan terhadap market to book ratio, dari persamaan regresi $\mathrm{Ln} \mathrm{MBR}=1,510-0,606 \mathrm{Ln} \mathrm{PP}+\varepsilon$. Hipotesis penelitian $\mathrm{H}_{\mathrm{o}}$ ditolak dan menerima hipotesis $\mathrm{H}_{\mathrm{a}}$ yaitu $\mathrm{t}_{\text {hitung }}-2,070>\mathrm{t}_{\text {tabel }}-2,00247$ dengan tingkat signifikasi 0,043 lebih kecil dari $5 \%$ atau 0,05 . Artinya perputaran piutang berpengaruh negatif dan signifikan terhadap market to book ratio pada Perusahaan Sub Sektor Tekstil dan Garmen yang listing di Bursa Efek Indonesia.

Kata Kunci: Perputaran Piutang dan Market to Book Ratio

\section{Abstract}

This research aims to analyze the effect of turnover receivable against the company in the proxy value using the market to book ratio on the company's Textile and Garment Sector Sub listings in Indonesia Stock Exchange. The analysis of the data used in this research is descriptive qualitative and quantitative analyses. The sample used is the Sub sectors of textiles and Garment that listings in Indonesia stock exchange in 2009 up to 2013 which have met the criteria of withdrawal of samples based on the Purposive sampling of as many as 15 companies.

Regression test results showed that the turnover of receivables the negative and significant effect on the market to book ratio. It can be seen from the regression equation $\mathrm{Ln} \mathrm{MBR}=1,510-0,606 \mathrm{Ln} \mathrm{PP}+\varepsilon$. The research hypothesis $H o$ is rejected and accepted the alternative hypothesis $\mathrm{Ha}-t_{\text {test }}>-t_{\text {table }},-2,070>-2,00247$ with the significance level 0,043 is smaller than 5\% or 0.05, it can be concluded that the turnover of receivables has a negative and significant effect to the market to book ratio in the Sub Sector Companies Textiles and Garment listed in Indonesia Stock Exchange.

Keywords: Turnover Receivable and Market to Book Ratio

\section{A. PENDAhuluan}

\section{Latar Belakang Masalah}

Salah satu tujuan perusahaan yang terpenting adalah memperoleh laba atau keuntungan yang maksimal. Tidak hanya untuk memperoleh laba, perusahaan juga mempunyai tujuan untuk memakmurkan para pemegang saham serta memaksimalkan nilai perusahaan yang tercermin dari harga saham. Harga saham yang semakin meningkat mengindikasikan nilai yang baik bagi perusahaan.

Nilai perusahaan dapat diukur dengan berbagai analisis salah satunya adalah market to book ratio menyajikan penilaian tentang bagaimana investor memandang kinerja bagi perusahaan. Rasio ini berhubungan dengan harga dari saham perusahaan terhadap nilai bukunya..

Perputaran piutang merupakan salah satu indikator untuk menilai efisiensi nilai bagi perusahaan. Perputaran piutang yang tinggi maka kondisi modal yang ada akan semakin tinggi dan perusahaan dikatakan liquid. Apabila perputaran piutang rendah maka kondisi modal yang ada juga akan dikatakan illiquid atau tidak liquid. Beberapa peneliti terdahulu yang meneliti pengaruh perputaran piutang terhadap nilai perusahaan tidak semuanya menghasilkan kesimpulan yang sama. Sebagian besar hasil penelitian menyimpulkan bahwa perputaran piutang mempunyai pengaruh yang positif dan signifikan terhadap nilai perusahaan. Namun ada juga peneliti yang menyimpulkan bahwa perputaran piutang tidak mempunyai pengaruh terhadap nilai perusahaan. Kemungkinan berbedanya hasil penelitian di atas dikarenakan objek penelitian adalah pada perusahaan yang berbeda jenis operasionalnya.

\section{Rumusan Masalah}

Berdasarkan latar belakang masalah yang telah diuraikan di atas maka rumusan masalah dalam penelitian ini adalah : 
a. Bagaimana gambaran perputaran piutang dan nilai perusahaan pada Perusahaan Sub Sektor Tekstil dan Garmen yang listing di Bursa Efek Indonesia?

b. Apakah terdapat pengaruh perputaran piutang terhadap nilai perusahaan pada Perusahaan Sub Sektor Tekstil dan Garmen yang listing di Bursa Efek Indonesia?

\section{Tujuan Penelitian}

a. Untuk mengetahui gambaran perputaran piutang dan nilai perusahaan pada Perusahaan Sub Sektor Tekstil dan Garmen yang listing di Bursa Efek Indonesia.

b. Untuk mengetahui dan menganalisis pengaruh perputaran piutang terhadap nilai perusahaan pada Perusahaan Sub Sektor Tekstil dan Garmen yang listing di Bursa Efek Indonesia.

\section{Metode Penelitian}

Objek dalam penelitian ini adalah Perusahaan yang termasuk ke dalam Sub Sektor Tekstil dan Garmen yang telah tercatat di Bursa Efek Indonesia per tanggal 31 Desember 2013 dan yang telah mengaudit laporan keuangannya secara berturut-turut selama periode tahun 2009-2013 sehingga diperoleh 15 perusahaan.

Metode analisis yang digunakan untuk menguji hipotesis dalam penelitian ini adalah analisis regresi linier sederhana dan oleh karenanya uji asumsi klasik harus terlebih dahulu dilakukan. Uji asumsi klasik yang dilakukan antara lain uji normalitas, uji heteroskedastisitas dan uji autokorelasi. Teknik analisis data dalam penelitian ini menggunakan alat bantu software SPSS (Statistical Product and Service Solutions)

\section{B. TINJAUAN PUSTAKA}

\section{Laporan Keuangan}

Tujuan laporan keuangan menurut Martani, dkk. (2012:9) adalah memberikan informasi mengenai posisi keuangan, kinerja keuangan, dan arus kas entitas yang bermanfaat bagi sebagian besar kalangan pengguna laporan keuangan untuk keputusan ekonomi. Laporan keuangan juga menunjukkan hasil pertanggungjawaban manajemen atas penggunaan sumber daya yang dipercayakan kepada mereka.

Jenis-jenis laporan keuangan menurut Martani, dkk. (2012:10) adalah sebagai berikut:

a. Laporan Posisi Keuangan

Adalah daftar yang sistematis dari asset, utang, dan modal pada tanggal tertentu, yang biasanya dibuat pada akhir tahun disebut sebagai daftar yang sistematis, karena disusun berdasarkan urutan tertentu.

\section{b. Laporan Laba Rugi Komprehensif}

Adalah ikhtisar mengenai pendapatan dan beban suatu entitas untuk periode tertentu, sehingga dapat diketahui laba yang diperoleh dan rugi yang dialami. c. Laporan Arus Kas

Adalah suatu laporan yang menunjukkan aliran uang yang diterima dan digunakan perusahaan di dalam suatu periode akuntansi, beserta sumbersumbernya. Dengan adanya laporan ini, pemakai laporan keuangan dapat mengevaluasi perubahan asset neto entitas, struktur keuangan (termasuk likuiditas dan solvabilitas) dan kemampuan entitas untuk menghasilkan kas di masa mendatang.

\section{d. Laporan Perubahan Ekuitas}

Adalah laporan yang menunjukkan perubahan ekuitas untuk periode tertentu, biasa satu bulan atau satu tahun. Melalui laporan perubahan modal, pembaca laporan dapat mengetahui sebab-sebab perubahan ekuitas selama periode tertentu.

e. Catatan Atas Laporan Keuangan

Adalah laporan yang berisi informasi tambahan atas apa yang disajikan dalam empat laporan di atas. Laporan ini memberikan penjelasan atau rincian pospos yang disajikan dalam laporan keuangan dan informasi mengenai pos-pos yang tidak memenuhi kriteria pengakuan dalam laporan keuangan.

\section{Rasio Keuangan}

Salah satu cara memperoleh informasi yang bermanfaat dari laporan keuangan perusahaan adalah dengan melakukan analisis laporan keuangan. Rasio keuangan di desain untuk memperlihatkan hubungan antar akun pada laporan keuangan. Menurut Kasmir (2010:93), rasio keuangan merupakan kegiatan membandingkan angka-angka dalam laporan keuangan dengan cara membagi satu angka dengan angka lainnya. Sedangkan rasio-rasio keuangan menurut Sudana (2011:20) ada 5 jenis yaitu:

a. Leverage Ratio

Yaitu rasio mengukur berapa besar penggunaan utang dalam pembelanjaan perusahaan.

b. Liquidity Ratio

Yaitu rasio mengukur kemampuan perusahaan untuk memenuhi kewajiban keuangan jangka pendek.

c. Activity Ratio

Yaitu rasio mengukur efektivitas dan efisiensi perusahaan dalam mengelola aktiva yang dimiliki perusahaan.

\section{d. Profitability Ratio}

Yaitu rasio mengukur kemampuan perusahaan untuk menghasilkan laba dengan menggunakan sumber-sumber yang dimiliki perusahaan, seperti asset, modal atau penjualan perusahaan.

\section{e. Market Value Ratio}

Rasio ini terkait dengan penilaian kinerja saham perusahaan yang telah diperdagangkan di pasar modal (go public).

\section{Piutang}

a. Pengertian Piutang

Menurut Kieso, et. al. (2007:346), piutang adalah klaim uang, barang atau jasa kepada pelanggan atau pihak-pihak lainnya. Piutang merupakan aktiva atau kekayaan perusahaan yang timbul sebagai akibat dari dilaksanakannya kebijakan penjualan kredit.

Menurut Halim (2007:138), pada dasarnya ada 4 aspek penting dalam manajemen piutang, yaitu 
masalah kebijakan kredit (credit policy) yang meliputi hal-hal berikut:

1) Standar kredit (credit standard)

2) Kebijakan pengumpulan piutang (collectionpolicy)

3) Penetapan jangka waktu kredit (credit term)

4) Potongan tunai (cash discount)

b. Faktor-faktor yang Mempengaruhi Investasi dalam Piutang

Menurut Halim (2007:139), ada beberapa faktor yang mempengaruhi besarnya investasi dalam piutang yaitu:

1) Volume Penjualan Kredit

2) Syarat Pembayaran bagi Penjualan Kredit

3) Ketentuan Tentang Batas Volume Penjualan Kredit

\section{c. Pengendalian Piutang}

Ditinjau dari manajemen preventif, pada dasarnya terdapat 3 bidang pengendalian yang umum dilakukan. Menurut Halim (2007:136), ketiga bidang tersebut adalah:

1. Pemberian kredit, dalam hal ini kebijakan kredit dan syarat penjualan kredit tidak boleh menghambat pelanggan. Keadaan keuangannya juga tidak boleh menimbulkan kerugian yang besar karena adanya piutang yang menunggak/ tidak dapat ditagih dapat merugikan perusahaan.

2. Penagihan yang aktif, dalam hal ini harus dilakukan usaha yang aktif untuk memperoleh pembayaran atas piutang yang ada sesuai dengan syarat penjualan kredit .

3. Penyelenggaraan administrasi piutang yang baik, meskipun prosedur-prosedur pemberian kredit dan penagihan telah dilakukan dengan baik, namun jika administrasi atas piutang tersebut kurang baik maka tidak dapat menjamin bahwa pengendalian piutangnya telah efektif.

\section{d. Perputaran Piutang}

Menurut Kieso, et. al. (2007:368), rasio perputaran piutang (Receivable Turnover Ratio) adalah mengukur berapa kali secara rata-rata piutang berhasil ditagih selama satu periode. Rasio ini dihitung dengan membagi penjualan bersih dengan piutang rata-rata (bersih) yang beredar selama tahun berjalan. Piutang rata-rata bersih dapat dilihat dengan menjumlahkan antara piutang tahun sebelumnya dengan piutang pada tahun berjalan dibagi dua maka akan terlihat nilai dari rata-rata piutang bersih atau total rata-rata piutang.

Perputaran Piutang $=\quad$ Penjualan bersih

Piutang usaha rata-rata bersih

Sedangkan menurut Horne dan John (2012:172), rasio perputaran piutang (Receivable Turnover-RT) memberikan pandangan mengenai kualitas piutang perusahaan dan seberapa berhasilnya perusahaan dalam penagihannya. Rasio ini dihitung dengan membagi piutang ke dalam penjualan kredit tahunan.

Perputaran Piutang $=\underline{\text { Penjualan kredit tahun netto }}$ Piutang
Menurut Kieso, et. al. (2007:368), faktor-faktor yang mempengaruhi perputaran piutang adalah penjualan kredit bersih, rata-rata piutang yang beredar serta skedul umur piutang. Sedangkan menurut Sudana (2011:223), faktor-faktor yang menyangkut perputaran piutang adalah syarat penjualan (jangka waktu kredit, potongan tunai dan jangka waktu potongan), analisis kredit (character, Capacity, capital, collateral dan condition) serta kebijakan penagihan piutang.

\section{Nilai Perusahaan}

Menurut Husnan (1998:36), nilai perusahaan merupakan nilai yang dibutuhkan investor untuk mengambil keputusan investasi yang tercermin dari harga pasar perusahaan. Nilai perusahaan pada dasarnya dapat diukur dari beberapa aspek salah satunya adalah harga pasar saham perusahaan. Rasio nilai pasar (Market Value Ratio) yaitu rasio yang berhubungan dengan harga saham perusahaan terhadap laba, arus kas, dan nilai buku per sahamnya. Menurut Brigham dan Joel (2012:150), terdiri atas:

a. Rasio harga/laba (Price/Earning-P/E)

$$
=\quad \text { Harga per saham }
$$

b. Rasio harga/arus kas (Price/Cash Flow Ratio)

$$
=\quad \text { Harga per saham }
$$

Arus kas per saham

c. Rasio nilai pasar/nilai buku (Market Book-M/B)

$$
=\frac{\text { Harga pasar per saham }}{\text { Nilai buku per saham }}
$$

\section{Pengaruh Perputaran Piutang Terhadap Nilai} Perusahaan

Teori yang dikemukakan oleh Weston dan Thomas (1999), menyatakan bahwa tingkat perputaran piutang, perputaran asset dan perputaran persediaan berpengaruh terhadap nilai perusahaan. Perputaran piutang yang menjadi salah satu indikator yang dapat mempengaruhi nilai bagi perusahaan. Perputaran piutang yang dimaksud adalah kemampuan perusahaan dalam mengelola manajemen piutangnya. Semakin tinggi tingkat perputaran piutang maka semakin baik pengelolaan piutang perusahaan yang dapat mempengaruhi nilai perusahaan.

\section{PEMBAHASAN}

\section{Analisis}

\section{a. Analisis Deskriptif Kualitatif}

Perputaran piutang terendah ada pada perusahaan Sunson Textile Manufacture dengan kisaran angka 2,738 yang terjadi pada tahun 2011. Akan tetapi di sisi lain, perusahaan Sunson Textile Manufacture juga mencapai angka total perputaran piutang yang paling tinggi yaitu 47,9994 pada tahun 2010.

Nilai market to book ratio terendah dimiliki oleh emiten Asia Pasific Fiber Tbk sebesar -53,0694 pada tahun 2009. Tingkat market to book ratio 
tertinggi dimiliki oleh Nusantara Inti Corpora yakni sebesar 13,7986 pada tahun 2009. Dari hasil penelitian selanjutnya, diketahui rata-rata market to book ratio adalah $-1,01895$.

\section{b. Analisis Deskriptif Kuantitatif}

Hasil persamaan regresi linier sederhana adalah sebagai berikut: $\mathrm{Ln} \mathrm{MBR}=1,510-0,606 \mathrm{Ln}$ $\mathrm{PP}+\varepsilon$. Persamaan regresi di atas dapat diartikan bahwa terdapat pengaruh negatif antara perputaran piutang dengan nilai perusahaan yang diproksikan dengan market to book ratio pada Perusahaan Sub Sektor Tekstil dan Garmen yang listing di Bursa Efek Indonesia.

Dari tabel koefisien korelasi (R) adalah sebesar 0,264. Dengan melihat kriteria koefisien korelasi pada tabel 5 dapat dikatakan bahwa hubungan antara perputaran piutang dengan market to book ratio pada Perusahaan Sub Sektor Tekstil dan Garmen yang listing di Bursa Efek Indonesia sangat lemah.

Hasil pengolahan data SPSS 20 pada tabel menunjukkan bahwa R Square adalah sebesar 0,070 artinya variasi variabel perputaran piutang memiliki kekuatan 7\% dalam mengestimasi market to book ratio dan sisanya sebesar 93\% dijelaskan oleh variabel lain di luar variabel dalam penelitian ini seperti perputaran kas dan perputaran persediaan.

Kriteria hipotesis untuk menguji signifikansi koefisien persamaan regesi adalah sebagai berikut:

1. Jika $t_{\text {hitung }}>t_{\text {tabel }}$ atau $-t_{\text {hitung }}<-t_{\text {tabel }}$ dengan nilai probabilitas $<0,05$ maka $\mathrm{H}_{\mathrm{o}}$ ditolak dan $\mathrm{H}_{\mathrm{a}}$ diterima

2. Jika $t_{\text {hitung }}<t_{\text {tabel }}$ atau $-t_{\text {hitung }}>-t_{\text {tabel }}$ dengan tingkat probabilitas >0,05 maka $\mathrm{H}_{0}$ diterima dan $\mathrm{H}_{\mathrm{a}}$ ditolak

Kriteria pengambilan keputusan menggunakan taraf nyata 5\% untuk diuji 2 arah $(\alpha / 2)$ $=0,05 / 2=0,025$. Dengan tingkat kepercayaan $95 \%$, $\mathrm{n}=59$ dan df sebesar $\mathrm{n}-2=59-2=57$, dari tabel $\mathrm{t}$ pada lampiran 5 diperoleh angka $t_{\text {tabel }}$ sebesar 2,00247 . Sedangkan nilai $t_{\text {hitung }}$ dapat dilihat pada tabel 23 sebesar $-2,070$ dan $t_{\text {tabel }}$ sebesar $-2,00247$ dengan nilai signifikansi pada tabel 23 sebesar 0,043 , sehingga hipotesis Ho ditolak dan menerima hipotesis alternatif $\mathrm{H}_{\mathrm{a}}$ yaitu $\mathrm{t}_{\text {hitung }}-2,070<\mathrm{t}_{\text {tabel }}-$ 2,00247 , artinya perputaran piutang berpengaruh negatif dan signifikan terhadap nilai perusahaan dengan proksi market to book ratio pada Perusahaan Sub Sektor Tekstil dan Garmen yang listing di Bursa Efek Indonesia.

\section{Evaluasi}

a. Perputaran Piutang Pada Perusahaan Sub Sektor Tekstil dan Garmen yang Listing Di Bursa Efek Indonesia

Hasil penelitian menunjukkan bahwa kondisi perputaran piutang pada Perusahaan Sub Sektor Tekstil dan Garmen yang listing di Bursa Efek Indonesia tahun 2009-2013 berfluktuasi. Dapat dilihat pada perputaran piutang tahun 2009 memiliki tingkat perputaran piutang yang tinggi yaitu 47,99\%.
Sedangkan perputaran piutang terendah sebesar 2,738\% pada tahun 2010. Penurunan ini mengindikasikan sinyal yang kurang baik bagi para investor sebab tingkat perputaran piutang rendah yang menunjukkan kemampuan perusahaan dalam mengelola piutangnya masih kurang baik. Sedangkan rata-rata perputaran piutang sebesar 9.6521dan perusahaan yang berada di atas rata-rata perputaran piutang adalah sebanyak 6 perusahaan serta perusahaan di bawah rata-rata perputaran piutang sebanyak 9 perusahaan. Hal ini menunjukkan bahwa manajemen pengelolaan piutang masih kurang baik yang dapat dilihat dari banyaknya perusahaan yang memiliki nilai di bawah rata-rata perputaran piutang.

b. Market to Book Ratio Pada Perusahaan Sub Sektor Tekstil dan Garmen yang Listing Di Bursa Efek Indonesia

Hasil penelitian menunjukkan bahwa market to book ratio tahun 2009-2013 senantiasa berfluktuasi. Market to book ratio tertinggi yakni pada emiten Nusantara Inti Corpora tahun 2009 sebesar 13,7986. Pada tahun 2010-2013 market to book ratio emiten Nusantara Inti Corpora mengalami penurunan yang signifikan pada tahun 2010 market to book ratio sebesar 5,0249.

Rata-rata market to book ratio adalah -1,0190 dan perusahaan yang berada di atas rata-rata market to book ratio sebanyak 12 perusahaan serta perusahaan dengan market to book ratio di bawah rata-rata sebanyak 3 perusahaan. Hal ini menunjukkan bahwa memberi sinyal negatif dan pandangan yang kurang baik bagi para investor. Dimana, kondisi ini menunjukkan bahwa rata-rata harga pasar saham Perusahaan Sub Sektor Tekstil dan Garmen adalah sebesar $-1,0190$ kali dibandingkan dengan nilai bukunya. Ini berarti harga saham Perusahaan dihargai oleh investor lebih rendah dari nilai bukunya.

\section{KESIMPULAN DAN SARAN}

\section{Kesimpulan}

a. Rata-rata perputaran piutang pada Perusahaan Sub Sektor Tekstil dan Garmen yang listing di Bursa Efek Indonesia tahun 2009 sampai dengan 2013 adalah sebesar 9,6521.

b. Rata-rata market to book ratio pada Perusahaan Sub Sektor Tekstil dan Garmen yang listing di Bursa Efek Indonesia adalah sebesar -1,0190 kali. Perusahaan yang berada di atas rata-rata market to book ratio sebanyak 12 perusahaan dan di bawah rata-rata sebanyak 3 perusahaan.

c. Hasil pengujian regresi menunjukkan bahwa perputaran piutang berpengaruh negatif dan signifikan terhadap market to book ratio. Hal ini dapat dilihat dari persamaan regresi Ln MBR = $1,510-0,606$ Ln PP + yang berarti bahwa setiap kenaikan perputaran piutang sebesar $1 \%$ akan diikuti penurunan market to book ratio sebesar $0,606 \%$ dan sebaliknya setiap penurunan perputaran piutang sebesar 1\% akan diikuti kenaikan market to book ratio sebesar $0,606 \%$. 
d. Hasil pengujian korelasi menunjukkan nilai sebesar 0,264 sehingga dapat di katakan bahwa hubungan antara perputaran piutang dengan market to book ratio pada Perusahaan Sub Sektor Tekstil dan Garmen yang listing Di Bursa Efek Indonesia sangat lemah.

e. Dari hasil pengujian R Square yang di proksikan dengan market to book ratio yaitu hanya sebesar $7 \%$ dan selebihnya $93 \%$ dipengaruhi oleh variabel lain di luar variabel perputaran piutang seperti perputaran kas dan perputaraan persediaan.

f. Hasil dari uji t menunjukkan bahwa $t_{\text {hitung }}-2,070$ $<t_{\text {tabel }}-2,00247$ dengan tingkat signifikansi 0,043 .

\section{Saran}

a. Sebaiknya para manajer perusahaan hendaknya lebih memperhatikan kembali mengenai pengelolaan manajemen piutang dalam perusahaan agar perputaran piutang semakin tinggi agar mendapatkan nilai yang baik dari para pemegang saham

b. Sebaiknya para investor dan calon investor yang berencana berinvestasi pada Perusahaan Sub Sektor Tekstil dan Garmen yang listing di Bursa Efek Indonesia hendaknya memperhatikan dan menganalisis tingkat perputaran piutang dan market to book ratio perusahaan.

c. Bagi peneliti selanjutnya yang ingin meneliti di sektor yang sama, sebaiknya menambahkan variabel lain di luar variabel dalam penelitian ini seperti perputaran kas, perputaran persediaan dan sebaiknya pada sektor yang lainnya serta memperpanjang periode penelitian.

\section{E. DAFTAR PUSTAKA}

Bursa Efek Indonesia, http://www.idx.co.id, diakses 9 Juli 2014.

Brigham, Eugene F. dan Joel F. Houston, 1999, Dasar-Dasar Manajemen Keuangan, Edisi Kesebelas, Jilid Satu, Jakarta: Salemba Empat.

Halim, Abdul, 2007, Manajemen Keuangan Bisnis, Malang: Ghalia Indonesia.

Horne, James C. Van dan John M. Wachowicz, Jr., 2012, Prinsi-Prinsip Manajemen Keuangan, Edisi Ketigabelas, Jilid Satu, Jakarta: Salemba Empat.

Husnan, Suad, 1998, Manajemen Keuangan Teori dan Penerapan (Keputusan Jangka Panjang), Edisi Keempat, Cetakan Ketiga, Yogyakarta: BPFE UGM.

Kasmir, 2010, Bank dan Lembaga Keuangan Lainnya, Edisi Keenam, Jakarta: PT Raja Grafindo Persada.

Kieso E, Donald, Jerry J Weygant dan Terry D Warfield, 2007, Manajemen Keuangan, Jilid Satu, Jakarta: Erlangga.

Martani, dkk., 2012, Akuntansi Keuangan Menengah Berbasis PSAK, Jakarta : Salemba Empat.

Sudana, 2011, Dasar-Dasar Manajemen Keuangan, Jakarta: Salemba Empat

Weston, J. Fred dan Thomas E. Copelland, 1999, Manajemen Keuangan, Edisi Kedelapan, Jilid Satu, Jakarta: Erlangga. 